\title{
Streptozotocin-induced diabetes lowers retinol-binding protein and transthyretin concentrations in rats
}

\author{
BY P. J. TUITOEK ${ }^{1}$, S. J. RITTER ${ }^{2}$, J. E. SMITH² AND T. K. BASU ${ }^{1 *}$ \\ ${ }^{1}$ Department of Agricultural, Food and Nutritional Science, University of Alberta, Edmonton, \\ Alberta, Canada T6G 2 P5 \\ ${ }^{2}$ Nutrition Department, The Pennsylvania State University, University Park, PA 16802-6504, USA
}

(Received 22 May 1995 - Revised 12 March 1996-Accepted 26 April 1996)

\begin{abstract}
Retinol-binding protein (RBP) and transthyretin (TTR) in the plasma, liver and kidney, retinol in plasma, and total vitamin $A$ in the liver were measured in rats 6 weeks after diabetes mellitus had been induced by streptozotocin (STZ). The diabetic rats gained $83 \%$ less weight despite consuming $45 \%$ more feed than the non-diabetic controls. Plasma and kidney concentrations of RBP and TTR were significantly lower in diabetic than in the non-diabetic control rats. Unlike the retinol carrier proteins, plasma albumin concentrations remained unaffected. Plasma concentrations of retinol were decreased while its hepatic levels increased in the diabetic animals. The depressed circulatory levels of retinol may reflect an altered metabolism of its transport proteins.
\end{abstract}

Streptozotocin: Diabetes mellitus: Retinol-binding protein: Transthyretin: Vitamin A

Vitamin A status is of concern in patients with diabetes mellitus as indicated by decreased concentrations of plasma retinol and its carrier, retinol-binding protein (RBP) (Basu et al. 1989; Krempf et al. 1991; Martinoli et al. 1993). Decreased plasma retinol and increased hepatic vitamin A concentrations have been associated with streptozotocin (STZ)-induced diabetes in rats (Basu et al. 1990). Vitamin A supplementation of the diets of these animals does not improve the circulatory status of retinol while liver concentration further increases (Tuitoek et al. 1996). The increased hepatic vitamin A concentrations do not appear to be due to increased intestinal absorption (Tuitoek et al. 1994) but may be attributed in part to the increased feed consumption by diabetic rats (Basu et al. 1990). However, the fact that plasma retinol levels are low in diabetic rats, despite the increased hepatic store size of the vitamin, is consistent with a defect in mobilization of vitamin A from the liver.

Liver vitamin A is stored predominantly as retinyl esters (Goodman \& Blaner, 1984). Its mobilization requires hydrolysis of retinyl ester to free retinol. This is subsequently conjugated with RBP (molecular weight $21000 \mathrm{Da}$ ) synthesized by the liver (Goodman, 1974). The retinol-RBP complex (holo-RBP) is secreted into the circulation, where it binds with transthyretin (TTR), a thyroxine-binding protein (molecular weight $55000 \mathrm{Da}$ ) (Smith \& Goodman, 1979). When retinol is delivered to target cells, RBP loses its affinity for TTR, returns to the blood as apo-RBP (lacking retinol) and is then eliminated via glomerular filtration (Goodman, 1984).

Using STZ-induced diabetic rats, the present study was undertaken to investigate the distributions of RBP and TTR in the liver, kidney and plasma. The objective of this study was to examine if the reported decreased level of plasma retinol in diabetes is caused by a decreased availability of the retinol carrier proteins.

\footnotetext{
* For reprints.
} 


\section{MATERIALS AND METHODS}

\section{Animals and tissue collections}

Male Wistar rats were obtained from Charles River, Montreal, Canada. They were housed in stainless steel cages in a well-ventilated room maintained at $21^{\circ}$ and were on a $12 \mathrm{~h}$ light-dark cycle. Diabetes was induced by a single intravenous injection of STZ $(55 \mathrm{mg} / \mathrm{kg}$ ) (Upjohn, Kalamazoo, MI, USA) dissolved in 0.01 M-citrate buffer, pH 4.5. Control rats were injected with citrate buffer alone. Following injection with STZ, animals displaying plasma glucose concentrations greater than $18 \mathrm{mmol} / \mathrm{l}$ were considered diabetic. These diabetic animals, and the corresponding controls, were fed on a semipurified diet described elsewhere (Tuitoek et al. 1996) for 6 weeks. All animals were allowed free access to water, and records of feed intake and body weight were kept throughout the study. Animals were killed at the end of the study using a $\mathrm{CO}_{2}$ chamber. Blood was collected in heparinized tubes; separated plasma was protected from light and stored at $-20^{\circ}$, pending analysis. Livers and kidneys were removed, cleaned and frozen immediately in liquid $\mathbf{N}_{2}$.

\section{Radioimmunoassays}

For RBP and TTR analysis liver sections and kidneys were homogenized separately in 19 volumes of $250 \mathrm{~mm}$-sucrose with a Polytron homogenizer (Brinkmann, Westbury, NY, USA) at speed 5 for $15 \mathrm{~s}$. Portions of the homogenates were diluted with an equal volume of an aqueous Triton X-100 solution (20 g/l) to release the RBP and TTR trapped in subcellular organelles. The Triton X-100-treated homogenates were diluted 1500-fold (w/v) relative to the original tissue mass with assay buffer $(50 \mathrm{~mm}-\mathrm{Tris}-\mathrm{HCl}$ containing $10 \mathrm{~g}$

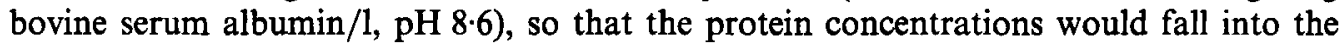
most sensitive regions of the respective standard curves. For the determination of RBP, TTR, and albumin in plasma, the samples were diluted with assay buffer (1500-fold for RBP; 10000-fold for TTR; and 700000-fold for albumin).

RBP (Smith et al. 1978, 1980), TTR (Navab et al. 1977) and albumin (Smith et al. 1978) were determined by the indicated radioimmunoassays. All samples were assayed in triplicate. The ${ }^{125}$ I-labelled proteins that were precipitated by the antisera were counted in a Packard 500C AutoGamma Counter (Packard Instrument Co., Meriden, CT, USA). The respective protein concentrations were calculated by a logit-log data reduction programme in the counter. The mean within-assay CV for replicates were 2.8 (SD 1.3) $\% ; 4.0$ (sD 3.0) $\%$; and 4.1 (SD $2 \cdot 4$ ) \% for the RBP, TTR and albumin radioimmunoassays respectively. To determine the molar concentrations a molecular weight of 21422 for RBP, based on the amino acid sequence of rat RBP (Sundelin et al. 1985a), was used, and a molecular weight of 54792, based on the amino acid sequence of rat TTR (Sundelin et al. 1985b), was used for TTR.

\section{Determination of vitamin $A$}

Plasma retinol (Nierenberg \& Lester, 1985) and liver total vitamin A (Leichter et al. 1991) were assayed by HPLC as described elsewhere (Tuitoek et al. 1996). Chromatography was performed on a C18 reverse-phase column (Whatman partisil SOD, $3.5 \mu \mathrm{m}$ particle size, $4.6 \mathrm{~mm}$ i.d. $\times 100 \mathrm{~mm}$ ), by use of a mobile phase consisting of methanol-water $(95: 5, \mathrm{v} / \mathrm{v})$. Detection was by u.v. absorption at $325 \mathrm{~nm}$, and quantification was performed by comparison of peak areas produced by the injection of known amounts of retinol. In order to determine the recovery efficiency of retinol, this compound $(5 \mu \mathrm{g} / \mathrm{ml})$ was added to plasma in hexane. The standard added to plasma, taken through the extraction procedure and injected into the HPLC, resulted in the recovery of $86.4 \%$. 
Table 1. Effect of streptozotocin-induced diabetes for 6 weeks on the body-weight gain, feed intake and glycaemic status of rats*

(Values are means with their standard errors)

\begin{tabular}{|c|c|c|c|c|c|}
\hline & \multicolumn{2}{|c|}{ Control (n 10) } & \multicolumn{2}{|c|}{ Diabetic (n 11) } & \multirow{2}{*}{$\begin{array}{c}\text { Student's } t \text { test } \\
\text { ( } P \text { value })\end{array}$} \\
\hline & Mean & SE & Mean & SE & \\
\hline \multicolumn{6}{|l|}{ Body weight (g) } \\
\hline Initial & 328 & $6 \cdot 9$ & 328 & $4 \cdot 1$ & NS \\
\hline Final & 437 & $4 \cdot 7$ & 346 & $7 \cdot 1$ & $<0.0001$ \\
\hline Feed intake $(g / d)$ & $25 \cdot 4$ & $0-4$ & $46-2$ & 1.5 & $<0.0001$ \\
\hline Plasma glucose (mmol/1) & 6.4 & $0 \cdot 16$ & $22 \cdot 8$ & $2 \cdot 8$ & $<0.0004$ \\
\hline
\end{tabular}

* For details of procedures, see pp. 892-893.

Table 2. Plasma concentrations of retinol, retinol transport proteins and albumin in streptozotocin-induced diabetic and control rats*

(Values are means with their standard errors)

\begin{tabular}{|c|c|c|c|c|c|c|c|}
\hline & \multicolumn{3}{|c|}{ Control } & \multicolumn{3}{|c|}{ Diabetic } & \multirow{2}{*}{$\begin{array}{l}\text { Student's } t \text { test } \\
\quad \text { ( } P \text { value) }\end{array}$} \\
\hline & Mean & SE & $n$ & Mean & $\mathbf{S E}$ & $n$ & \\
\hline Retinol $(\mu \mathrm{mol} / \mathrm{l})$ & $1 \cdot 32$ & 0.06 & 10 & 0.90 & 0.04 & 11 & 0.0001 \\
\hline $\operatorname{RBP}(\mu \mathrm{mol} / 1)$ & 3.72 & 0.09 & 10 & 2.24 & 0.17 & 11 & 0.0001 \\
\hline TTR $(\mu \mathrm{mol} / \mathrm{l})$ & 3.91 & 0.12 & 10 & 2.94 & 0.08 & 11 & 0.0001 \\
\hline Albumin $(\mathrm{g} / \mathrm{l})$ & 27.6 & 2.96 & 9 & $25 \cdot 2$ & $1 \cdot 17$ & 11 & $0 \cdot 16$ \\
\hline
\end{tabular}

RBP, retinol-binding protein; TTR, transthyretin.

* For details of procedures, see pp. 892-893.

\section{Statistical analysis}

Data were tabulated to give means and standard error of the mean using the SAS computer program (Statistical Analysis Systems, 1988). Student's $t$ test was used to determine differences between group means (Steel \& Torrie, 1980). The upper level of significance was preset at $P<0.05$. The data were tested for outliers that should be rejected, by the procedure of Dixon (1953).

\section{RESULTS}

Following the administration of STZ, animals developed hyperglycaemia of more than $.18 \mathrm{mmol} / 1$ within $48 \mathrm{~h}$, which persisted throughout the 6-week study period (Table 1 ). The initial body weights of diabetic rats were similar to those of control animals, but their final weights at the end of the study were significantly lower. Thus the diabetic animals gained less weight than did the corresponding controls $(+18$ (SE 7.6) g v. +109 (SE 3.1) g, $P<$ $0.0001)$, even though they consumed a significantly higher amount of feed per day.

Significantly lower plasma concentrations of RBP $(P<0.0001)$, TTR $(P<0.0001)$ and retinol $(P<0.05)$ were found in diabetic rats compared with non-diabetic controls (Table 2). Unlike the retinol carrier proteins, plasma albumin concentrations were not significantly different between the two groups with this number of animals. Liver concentrations of TTR $(P<0.0001)$ but not RBP $(P>0.05)$ were found to be significantly reduced by diabetes 
Table 3. Liver concentrations of retinol transport proteins in streptozoticin-induced diabetic and control rats*

(Values are means with their standard errors)

\begin{tabular}{lcccccc}
\hline \hline & \multicolumn{2}{c}{ Control $(n$ 10) } & & \multicolumn{2}{c}{ Diabetic $(n$ 11) } & \\
\cline { 2 - 3 } & Mean & SE & & Mean & SE & $\begin{array}{c}\text { Student's } t \text { test } \\
(P \text { value })\end{array}$ \\
\hline RBP $(\mathrm{nmol} / \mathrm{g})$ & 1.64 & 0.05 & & 1.48 & 0.08 & 0.13 \\
TTR $(\mathrm{nmol} / \mathrm{g})$ & 0.92 & 0.03 & & 0.54 & 0.02 & 0.0001 \\
Vitamin A $(\mu \mathrm{mol} / \mathrm{g})$ & 0.51 & 0.05 & & 1.03 & 0.02 & 0.0001 \\
Liver weight $(\mathrm{g})$ & 18.4 & 0.36 & & 16.4 & 0.38 & 0.002 \\
\hline \hline
\end{tabular}

RBP, retinol-binding protein; TTR, transthyretin.

* For details of procedures, see pp. 892-893.

Table 4. Kidney concentrations of retinol transport proteins in streptozotocin-induced diabetic and control rats*

(Values are means with their standard errors)

\begin{tabular}{lcccccc}
\hline \hline & \multicolumn{2}{c}{ Control $(n$ 10) } & & \multicolumn{2}{c}{ Diabetic $(n$ 11) } & \\
\cline { 2 - 3 } & Mean & SE & & Mean & sE & $\begin{array}{c}\text { Student's } t \text { test } \\
(P \text { value })\end{array}$ \\
\hline RBP (nmol/g) & 4.48 & 0.07 & & $4 \cdot 13$ & 0.12 & 0.02 \\
TTR (nmol/g) & 0.79 & 0.03 & & 0.56 & 0.02 & 0.0001 \\
Kidney weights (g) & 1.84 & 0.04 & & 2.15 & 0.04 & 0.0001 \\
\hline \hline
\end{tabular}

RBP, retinol-binding protein; TTR, transthyretin.

* For details of procedures, see pp. 892-893.

(Table 3). However, absolute amounts of RBP in the liver were significantly $(P<0.01)$ lower in the diabetic than in the control animals. Hepatic concentrations of vitamin $A$ were significantly higher in the diabetic than in the control animals $(P<0.0001)$. In the kidney, the tissue concentrations of both RBP $(P<0.05)$ and TTR $(P<0.0001)$ were depressed in the diabetic compared with the control animals (Table 4). However, total kidney RBP was not different between the two groups.

\section{DISCUSSION}

The results of the present study indicate that plasma retinol concentrations are significantly lower, and the hepatic concentrations of vitamin $\mathrm{A}$ are significantly higher in diabetic $v$. control animals. These results are in agreement with other studies in human subjects (Basu et al. 1989; Krempf et al. 1991; Martinoli et al. 1993) and animals (Basu et al. 1990; Tuitoek et al. 1996). Since it has been shown that the hepatic storage of vitamin A is proportional to its intake (Hicks et al. 1984), the increased liver concentrations of vitamin A may be explained in part by the increased feed intake $(>45 \%)$ of the diabetic animals.

The present study also examined the effect of diabetes on RBP and TTR in the plasma, liver and kidneys. The results showed that there were significant reductions in concentrations of both of these proteins in the plasma and kidneys. These effects appear to be specific since the plasma albumin concentrations remained constant. To the best of our knowledge, this is the only study in which plasma retinol carrier proteins have been 
measured in diabetic rats. The results are in agreement with the studies involving patients with insulin-dependent diabetes (IDDM) in whom plasma RBP as well as TTR concentrations were found to be significantly reduced (Basu et al. 1989; Kemp \& Frindik, 1991), while concentrations of other proteins such as albumin and transferrin remained unaffected (Kemp \& Frindik, 1991). The underlying reason for the reduced retinol carrier proteins in diabetes is not known. Earlier studies have shown that the diabetes-associated increase in hepatic vitamin A concentration (Basu et al. 1990) is further accentuated when vitamin $A$ is added to the diet without a significant improvement in the plasma retinol (Tuitoek et al. 1996).

In human subjects, retinol is normally found in plasma in a 1:1 molar ratio with RBP. It is surprising that the ratio in our control rats was only 0.36 . In view of limited data on the normal RBP values in rodents, the low retinol-RBP molar ratio in rats cannot be explained. According to one study, however, the percentage saturation of RBP with retinol appears to be $60-70 \%$ (Muto et al. 1972).

Acute and chronic diseases of the liver have been shown to be associated with decreased plasma vitamin A, RBP and TTR (Smith \& Goodman, 1971; McClain et al. 1979; Dickson et al. 1982). Since plasma albumin was not affected by diabetes in the present study, the decreased levels of RBP and TTR in the plasma and TTR in the liver may be an early indication of depressed protein synthesis. Furthermore STZ-induced diabetes has been shown to be associated with depressed synthesis of both secreted and non-secreted proteins in the liver (McNurlan \& Garlick, 1981). It has also been found in diabetic animals that although hepatic synthesis of some proteins, such as albumin, appear to be reduced as shown by decreased mRNA levels (Peavy et al. 1978), the serum albumin levels remain normal (Marsh, 1961). In the present study hepatic RBP levels were not affected significantly, suggesting that TTR may be a more sensitive index of impaired protein synthesis in diabetes. The formation of the RBP-TTR complex is thought to occur in plasma after independent secretion of the proteins from the hepatocyte (Goodman, 1984). The reduced secretion of TTR may decrease the formation of the RBP-TTR complex, resulting in an increased loss of RBP from the system. Since the plasma TTR molar concentration in the diabetic rats was 1.3 times the plasma molar RBP concentration, RBP is probably not being filtered in the kidney glomeruli at a greater rate because of the lower TTR concentrations.

Once RBP has delivered retinol to the target tissues, the resulting apoRBP has a reduced affinity for TTR. Due to its low molecular weight, the apoRBP rapidly undergoes glomerular filtration in the kidney (Peterson et al. 1974). Like other small proteins that undergo glomerular filtration the RBP is reabsorbed in the kidney tubules and seems to be catabolized (Mogielnicki et al. 1971). Only trace amounts of RBP appear in the urine unless kidney tubular function is impaired (Peterson \& Berggard, 1971). In conditions of impaired tubular function, such as Cd poisoning, an amount of RBP equivalent to the amount secreted into the plasma compartment can be excreted in the urine each day. However, these patients maintain normal plasma concentrations of RBP because the impaired tubular reabsorption does not influence the glomerular filtration rate (Vahlquist et al. 1973). Significant amounts of retinol and RBP have been reported to be excreted in the urine during acute infections (Stephensen et al. 1994). IDDM patients have also increased urinary excretion of RBP (Holm et al. 1987; Rowe et al. 1987). The urinary excretion of RBP was suggested to be an early sign of diabetic nephropathy. The low concentration of RBP in the kidneys of the diabetic rats probably reflects (1) the larger size of the kidneys in the diabetic rats and (2) a reduced secretion of RBP into the plasma. Therefore, less RBP is available to be removed by the kidneys, and the RBP that is removed is diluted in a greater area. 
The conclusion from the present study is that STZ-induced diabetes is associated with a depressed plasma concentration of retinol which may be due, at least in part, to its impaired metabolic transport from the liver.

\section{This research was supported by the Natural Sciences and Engineering Research Council of Canada.}

\section{REFERENCES}

Basu, T. K., Leichter, J. \& McNeill, J. H. (1990). Plasma and liver vitamin A concentrations in streptozotocin diabetic rats. Nutrition Research 10, 421-427.

Basu, T. K., Tze, W. J. \& Leichter, J. (1989). Serum vitamin A and retinol-binding protein in patients with insulindependent diabetes mellitus. American Journal of Clinical Nutrition 50, 329-331.

Dickson, P. W., Howlett, G. J. \& Schreiber, G. (1992). Metabolism of prealbumin in rats and changes induced by acute inflammation. European Journal of Biochemistry 129, 289-293.

Dixon, W. J. (1953). Processing data for outliers. Biometrics 9, 74-89.

Goodman, D. S. (1974). Vitamin A transport and retinol-binding protein metabolism. Vitamins and Hormones 32 , $167-180$.

Goodman, D. S. (1984). Plasma retinol-binding protein. In The Retinoids, vol. 2, pp. 41-48 [M. B. Sporn, A. B. Roberts and D. S. Goodman, editors]. Orlando, FL: Academic Press.

Goodman, D. S. \& Blanar, W. S. (1984). Biosynthesis, absorption and hepatic metabolism of retinol. In The Retinoids, vol. 2, pp. 1-39 [M. B. Sporn, A. B. Roberts and D. S. Goodman, editors]. Orlando, FL: Academic Press.

Hicks, V. A., Gunning, D. B. \& Olson, J. A. (1984). Metabolism, plasma transport and biliary excretion of radioactive vitamin $\mathrm{A}$ and its metabolites as a function of liver reserves of vitramin $\mathrm{A}$ in the rat. Journal of Nutrition 114, 1327-1333.

Holm, J., Hemmingsen, L., Nielsen, N. V. \& Thomsen, M. (1987). Increased urinary excretion of the retinolbinding protein in insulin-dependent diabetes mellitus in the absence of microalbuminuria. Clinica Chimica Acta 170, 345-350.

Kemp, S. F. \& Frindik, J. P. (1991). Effect of metabolic control on serum protein concentrations in diabetes. Acta Paediatrica Scandinavica 80, 938-943.

Krempf, M., Ranganathan, S., Ritz, P., Morin, M. \& Charbonnel, B. (1991). Plasma vitamin A and E in type 1 and type 2 adult diabetic patients. International Journal for Vitamin and Nutrition Research 61, 38-42.

Leichter, J., McNeill, J. H. \& Basu, T. K. (1991). Influence of insulin on plasma and liver vitamin A levels in diabetic rats. Journal of Clinical Biochemistry and Nutrition 11, 47-52.

McClain, C. J., Thiel, D. H., Parker, S., Badzin, L. K. \& Gilbert, H. (1979). Alterations in zinc, vitamin A and retinol-binding protein in chronic alcoholics: a possible mechanism for night blindness and hypogonadism Alcoholism: Clinical Experimental Research 3, 135-141.

McNurlan, M. A. \& Garlick, P. J. (1981). Protein synthesis in liver and small intestine in protein deprivation and diabetes. American Journal of Physiology 241, E238-E245.

Marsh, J. B. (1961). Effects of fasting and alloxan diabetes on albumin synthesis by perfused rat liver. American Journal of Physiology 201, 55-57.

Martinoli, L., Di Felice, M., Seghieri, G., Ciuti, M., De Giorgio, L. A., Fazzini, A., Gori, R., Anachini, R. \& Franconi, F. (1993). Plasma retinol and $\alpha$-tocopherol concentrations in insulin-dependent diabetes mellitus: their relationship to microvascular complications. International Journal for Vitamin and Nutrition Research 63 , 87-92.

Molgielnicki, R. P., Waldmann, T. A. \& Strober, W. (1971). The renal handling of low molecular weight proteins. 1. L-chain metabolism in experimental renal disease. Journal of Clinical Investigation 50, 901-909.

Muto, Y., Smith, J. E., Milch, P. O. \& Goodman, D. S. (1972). Regulation of retinol-binding protein metabolism by vitamin A status in the rat. Journal of Biological Chemistry 247, 2542-2550.

Navab, M., Smith, J. E. \& Goodman, D. S. (1977). Rat plasma prealbumin. Metabolic studies on effects of vitamin A status and tissue distribution. Journal of Biological Chemistry 252, 5107-5117.

Nierenberg, D. W. \& Lester, D. C. (1985). Determination of vitamins A and E in serum and plasma using a simplified clarification method and high performance liquid chromatography. Journal of Chromatography 345 , 275-284.

Peavy, D. E., Taylor, J. M. \& Jefferson, L. S. (1978). Correlation of albumin production rates and albumin mRNA levels in livers of normal, diabetic and insulin-treated diabetic rats. Proceedings of the National Academy of Sciences, USA 75, 5879-5883.

Peterson, P. A. \& Berggard, I. (1971). Isolation and properties of a human retinol-transporting protein. Journal of Biological Chemistry 246, 25-33.

Peterson, P. A., Nilsson, S. F., Östeberg, L., Rask, L. \& Vahlquist, A. (1974). Vitamins and Hormones 32, $181-214$. 
Rowe, D. J. F., Anthony, F., Polak, A., Shaw, K., Ward, C. D. \& Watts, G. F. (1987). Retinol binding protein as a small molecular weight marker of renal tubular function in diabetes mellitus. Annals of Clinical Biochemistry 24, 477-482.

Smith, F. R. \& Goodman, D. S. (1971). The effects of diseases of the liver, thyroid, and kidneys on the transport of vitamin A in human plasma. Journal of Clinical Investigation 50, 2426-2436.

Smith, J. E., Borek, C. \& Goodman, D. S. (1978). Regulation of retinol-binding protein metabolism in cultured rat liver cell lines. Cell 15, 865-873.

Smith, J. E., Dean, D. D., Sklan, D. \& Goodman, D. S. (1980). Colchicine inhibition of retinol-binding protein secretion by rat liver. Journal of Lipid Research 21, 229-237.

Smith, J. E. \& Goodman, D. S. (1979). Retinol-binding protein and the regulation of vitamin A transport. Federation Proceedings 38, $2504-2509$.

Statistical Analysis Systems (1988). SAS/STAT User's Guide, Release 6.03 Edition. Cary, NC: SAS Institute Inc.

Steel, R. G. D. \& Torrie, J. H. (1980). Principles and Procedures of Statistics: A Biometrical Approach, pp. 67-119. New York: McGraw-Hill.

Stephensen, C. B., Alvarez, J. P., Kohatsu, J., Hardmeier, R., Kennedy, J. I. Jr \& Grammon, R. B. Jr (1994). Vitamin $\mathrm{A}$ is excreted in the urine during acute infection. American Journal of Clinical Nutrition 60, 388-392.

Sundelin, J., Laurent, B. C., Anundi, H., Trägärdh, L., Larhammar, D., Björck, L., Erickson, U., Äckerström, B., Jones, A., Newcommer, M., Peterson, P. A. \& Rask, L. (1985a). Amino acid sequence homologies between rabbit, rat, and human serum retinol-binding proteins. Journal of Biological Chemistry 260, 6472-6480.

Sundelin, J., Melhus, M., Das, S., Erickson, U., Lind, P., Trägårdh, L., Peterson, P. A. \& Rask, L. (1985b). The primary structure of rabbit and rat prealbumin and comparison with the tertiary structure of human prealbumin. Journal of Biological Chemistry 260, 6481-6487.

Tuitoek, P. J., Rajotte, R. V., Thomson, A. B. R. \& Basu, T. K. (1994). Intestinal absorption of vitamin A in streptozotocin-induced diabetic rats. Diabetes Research 25, 151-158.

Tuitoek, P. J., Ziari, S., Tsin, A. T. C., Rajotte, R. V., Suh, M. \& Basu, T. K. (1996). Streptozotocin-induced diabetes in rats is associated with impaired metabolic availability of vitamin A (retinol). British Journal of Nutrition 75, 615-622.

Vahlquist, A., Peterson, P. A. \& Wibell, L. (1973). Metabolism of the vitamin A transporting protein complex. I. Turnover studies in normal persons and patients with chronic renal failure. European Journal of Clinical Investigation 3, 352-362. 